\title{
Study of genetic diversity in rapeseed and mustard germplasm by using cluster analysis
}

\begin{abstract}
The present study focuses on examining the genetic diversity in 104 accessions of rapeseed and mustard germplasm gathered from different regions of Pakistan. Correlation studies revealed positive correlation of yield component with morphological characters at $5 \%$ and $1 \%$ level of significance Cluster analysis divided the accessions into five major clusters I, II, III, IV and V. These diverse the germplasm are appropriate for planning of hybridization of programs.
\end{abstract}

Keywords: cluster, germplasm, accessions, diversity
Volume 6 Issue 5 - 2019

\author{
Muhammad Ahson Khan,' Irum Raza,' M Asif \\ Masood,' Saleem Abid, ${ }^{2}$ Saima Rani, ${ }^{2}$ Naheed \\ Zahra, ${ }^{2}$ Haider Abbas ${ }^{2}$ \\ 'Bio resources Conservation Institute, National Agriculture \\ Research Centre, Pakistan \\ ${ }^{2}$ Social Sciences Research Institute, National Agriculture \\ Research Centre, Pakistan \\ ${ }^{3}$ Crop Sciences Institute, National Agriculture Research Centre, \\ Pakistan
}

Correspondence: Irum Raza, Social Science Research Institute, NARC, Islamabad, Pakistan, Email irumraza83@gmail.com

Received: September 05, 2019 | Published: October 02, 2019

\section{Introduction}

Rapeseed (Brassica rapa and Brassica napus) and mustard (Brassica juncea), including the canola varieties, are among the most important oilseed crops in Pakistan. During 2010-2011, rapeseed and mustard were grown over an area of 203100 hectares in Pakistan out of which 17200 hectares were under canola varieties. Production of rapeseed and mustard was 176400 tons with 18600 tons of canola. ${ }^{1}$ During the year 2011-12, the total availability of edible oil in Pakistan was 2.748 million tonnes. Local production of edible oil was 0.636 million tonnes while 2.148 million tonnes were imported. ${ }^{2}$ In order to increase the production of edible oil in Pakistan, efforts are required to increase the production of oilseed crops including rapeseed and mustard. Introduction of canola varieties resulted in significant improvement of quality and production of rapeseed and mustard. However, in addition to the oil quality and seed characters, the genetic improvement for other economically important characters is also important. Study of genetic diversity in rapeseed and mustard germplasm is important for the selection of suitable genotypes for breeding programs. ${ }^{3-6}$ The present study was conducted to study the genetic diversity in germplasm resources of rapeseed and mustard from Pakistan for agro-morphological characters and selection of suitable material to be utilized in crop improvement.

\section{Material and methods}

A total of 104 accessions of rapeseed and mustard germplasm, including the landraces and cultivars, collected from different regions of Pakistan were used in the study. The experiment as conducted at Plant Genetic Resources Institute, National Agricultural Research Center, Islamabad. Germplasm accessions along with check variety Khanpur Raya were sown in the field during winter 2012-2013 using augmented design. Data were recorded for agro-morphological characters including days to 50 percent flowering, days to 100 percent flowering and days to maturity; qualitative morphological characters including leaf margin, leaf color, branching, mature leaf dissection, flower color, corolla shape, pedicel length and angle, leaf shape and stem shape; quantitative morphological characters including plant height, number of branches per plant, silique per raceme, raceme length, stem diameter, leaves per plant, pedicel length, leaf length, leaf width, silique width, silique length, seeds per silique and 100 grain weight. Ten plants of each accession were selected for data recording of qualitative and quantitative morphological characters and average was calculated for data analysis. Data for flowering and maturity was recorded from overall population of each accession.

Qualitative morphological characters were assessed through frequency distribution while in case of quantitative agro-morphological characters, frequency distribution, descriptive statistics correlation analysis and cluster analysis of germplasm were performed for all the characters using the software MINITAB 16.

\section{Results and discussion}

Frequency distribution for nine qualitative morphological characters in germplasm accessions (Table 1) showed a variation for all the characters except leaf color.

Frequency distribution for three physiological and twelve quantitative agro-morphological characters shows variation for all the characters studied (Figure 1). Descriptive statistics indicate that the variation is significant for all the characters (Table 2). Selection of suitable accessions for each character was made as shown in Table 3. The superior lines can be studied in detail for the development of short duration high yielding cultivars.

Correlation studies indicate the association of yield components with physiological and morphological characters (Table 4). Characters having positive correlation with yield components may help for the selection of promising lines (Figure 2).

Cluster analysis of germplasm on the basis of all the characters studied divided the germplasm into five major clusters at linkage distance of 20. The diverse germplasm accessions are suitable for the planning of hybridization programs. The dendrogram classified 104 accessions into 5 clusters based on the similarity of morphological characters within the clusters. A number of authors have made use of the cluster analysis technique for the determination of genetic similarity. The construction of dendrograms makes it possible to further visualize and interpret the findings of other studies. ${ }^{7-10}$ 
Table I Frequency distribution for qualitative morphological characters in 104 germplasm accessions and check variety of rapeseed and mustard

\begin{tabular}{|c|c|c|}
\hline Characters & Categories & Accessions \\
\hline \multirow[t]{2}{*}{ Branching } & Basal & II \\
\hline & Normal & 94 \\
\hline \multirow[t]{2}{*}{ Stem shape } & Irregular & 35 \\
\hline & Round & 70 \\
\hline Leaf color & Green & 105 \\
\hline \multirow[t]{4}{*}{ Leaf margins } & No serration & I \\
\hline & Crenate & 22 \\
\hline & Dentate & 48 \\
\hline & Doubly dentate & 34 \\
\hline \multirow[t]{4}{*}{ Leaf shape } & Elliptic & 74 \\
\hline & Orbicular & I \\
\hline & Ovate & 28 \\
\hline & Pandurate & 2 \\
\hline \multirow[t]{2}{*}{ Mature leaf dissection } & Lyrate & 95 \\
\hline & Parted & 10 \\
\hline \multirow[t]{2}{*}{ Pedicel length and angle } & Typical pedicel length and angle & 94 \\
\hline & Short and very close to stem & II \\
\hline \multirow[t]{3}{*}{ Flower color } & Light yellow & 10 \\
\hline & Yellow & 94 \\
\hline & White & I \\
\hline \multirow[t]{3}{*}{ Corolla shape } & Thin elliptical & 34 \\
\hline & Elliptical & 66 \\
\hline & Round & 5 \\
\hline
\end{tabular}

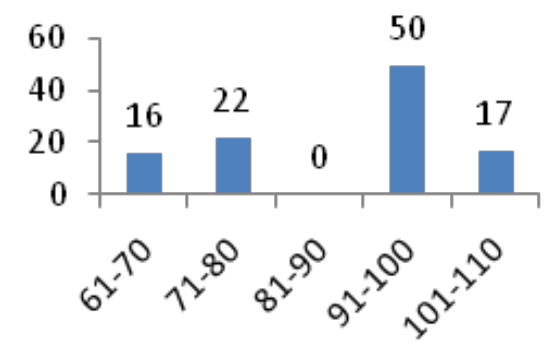

Days to 50 percent flowering

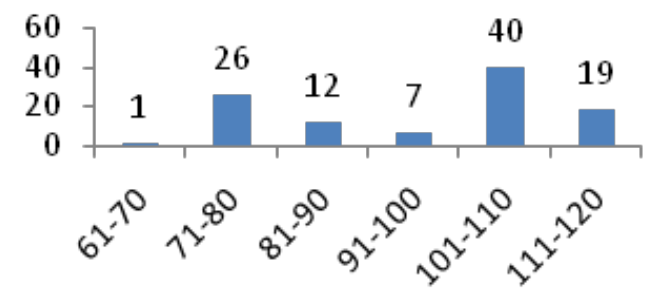

Days to 100 percent flowering

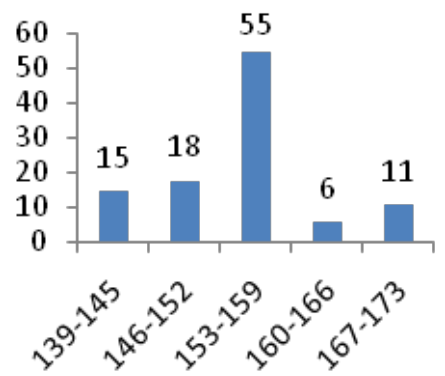

Days to maturity

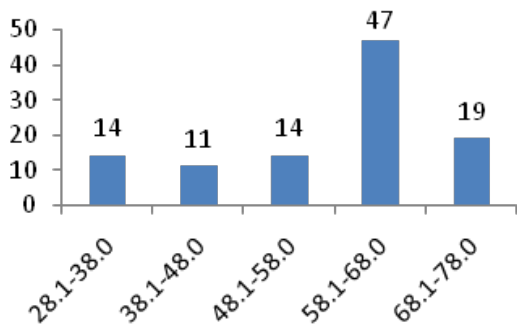

Plant height $(\mathrm{cm})$

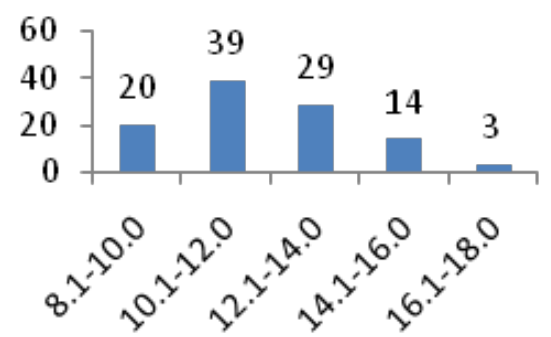

Number of branches per plant

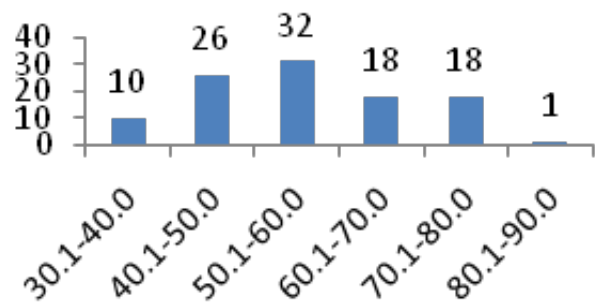

Number of silique per raceme

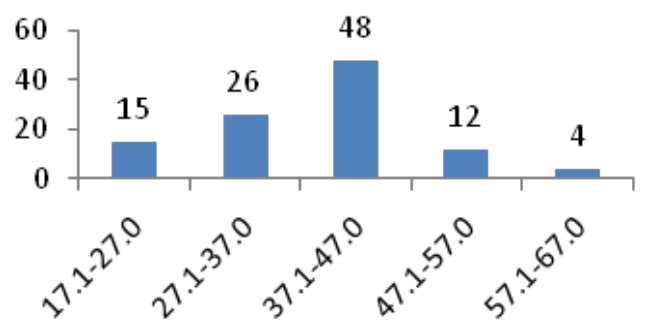

Raceme length $(\mathrm{cm})$ 


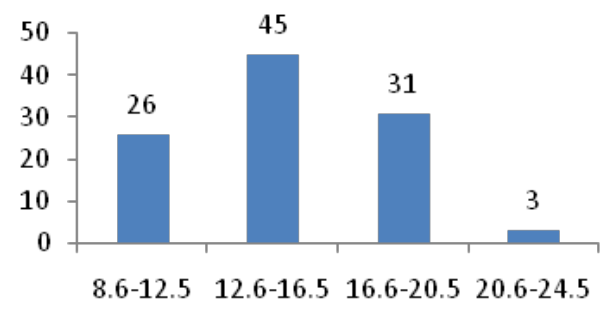

Stem diameter $(\mathrm{mm})$

Figure I(a) Frequency distrubution for quantitative agro-morphological characters in 104 germplasm accessions and check variety of rapeseed and mustard.

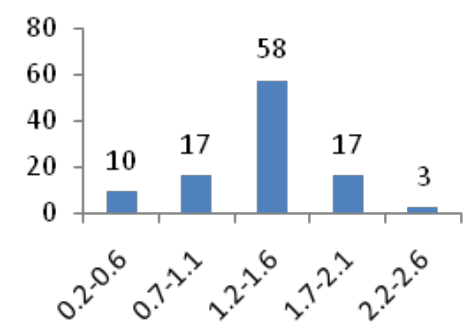

Pedicel length $(\mathrm{cm})$

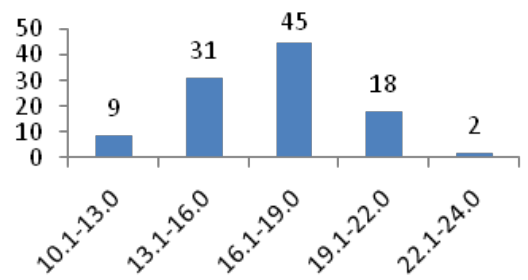

Number of leaves per plant

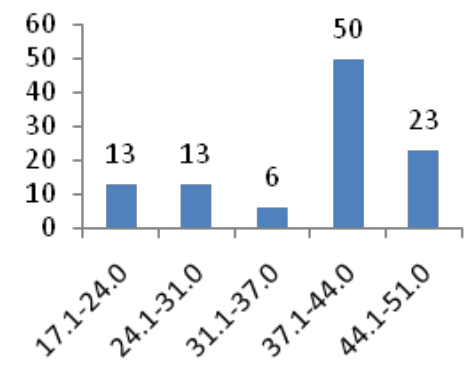

Leaf length $(\mathrm{cm})$

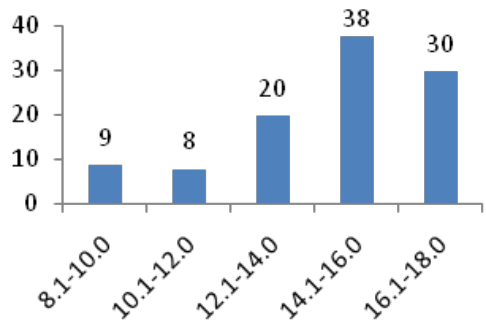

Leaf width $(\mathrm{cm})$

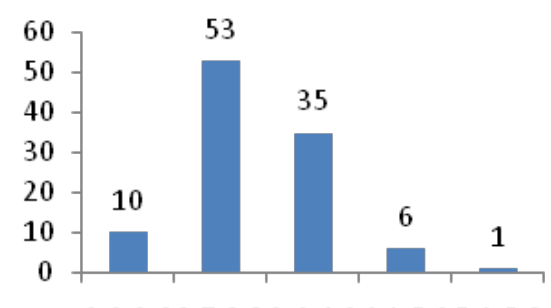

$2.0-2.62 .7-3.33 .4-4.04 .1-5.05 .1-5.8$

Silique width $(\mathrm{cm})$

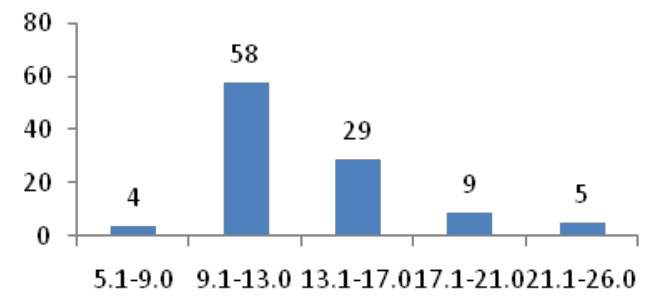

Seeds per silique

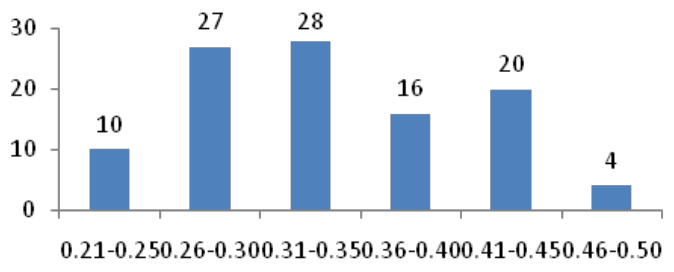

100 Grain weight

Figure I(b) Frequency distrubution for quantitative agro-morphological characters in 104 germplasm accessions and check variety of rapeseed and mustard.

Table 2 Descriptive statistics for quantitative agro-morphological characters in 104 germplasm accessions and check variety of rapeseed and mustard

\begin{tabular}{|c|c|c|c|c|c|}
\hline & Mean & $\begin{array}{l}\text { Standard } \\
\text { Error }\end{array}$ & $\begin{array}{l}\text { Sample } \\
\text { Variance }\end{array}$ & Minimum & Maximum \\
\hline $\begin{array}{l}\text { Days to } \\
50 \text { percent } \\
\text { flowering }\end{array}$ & 89.848 & $\mathrm{I} .407$ & 207.765 & 62 & 108 \\
\hline $\begin{array}{l}\text { Days to } \\
100 \text { percent } \\
\text { flowering }\end{array}$ & 95.457 & 1.499 & 235.789 & 66 & 114 \\
\hline $\begin{array}{l}\text { Days to } \\
\text { maturity }\end{array}$ & 153.695 & 0.836 & 73.31 & 139 & 174 \\
\hline Plant Height & 57.392 & 1.193 & 149.329 & 29.8 & 78 \\
\hline $\begin{array}{l}\text { Number of } \\
\text { branches per } \\
\text { plant }\end{array}$ & 12.018 & 0.188 & 3.726 & 8.6 & 17.6 \\
\hline $\begin{array}{l}\text { Number of } \\
\text { silique per } \\
\text { raceme }\end{array}$ & 55.73 & 1.2 & 151.298 & 30.5 & 81 \\
\hline Raceme length & 38.166 & 0.92 & 88.813 & 17 & 66.4 \\
\hline Stem diameter & 14.883 & 0.3 & 9.447 & 8.618 & 22.47 \\
\hline
\end{tabular}


Table Continues...

\begin{tabular}{|c|c|c|c|c|c|}
\hline & Mean & $\begin{array}{l}\text { Standard } \\
\text { Error }\end{array}$ & $\begin{array}{l}\text { Sample } \\
\text { Variance }\end{array}$ & Minimum & Maximum \\
\hline $\begin{array}{l}\text { Number of } \\
\text { leaves per } \\
\text { plant }\end{array}$ & 16.812 & 0.257 & 6.94 & 10.2 & 23 \\
\hline Pedical length & 1.332 & 0.041 & 0.18 & 0.32 & 2.44 \\
\hline Leaf length & 37.162 & 0.852 & 76.133 & 17.4 & 48.6 \\
\hline Leaf width & 14.432 & 0.238 & 5.955 & 8.1 & 17.86 \\
\hline Silique width & 3.287 & 0.054 & 0.307 & 1.958 & 5.7532 \\
\hline Silique length & 4.155 & 0.077 & 0.626 & 2.0336 & 5.984 \\
\hline $\begin{array}{l}\text { Seeds per } \\
\text { silique }\end{array}$ & 13.472 & 0.35 & 12.865 & 7.36 & 25.68 \\
\hline $\begin{array}{l}100 \text { Grain } \\
\text { weight }\end{array}$ & 0.338 & 0.007 & 0.005 & 0.2262 & 0.4736 \\
\hline
\end{tabular}

Table 3 Selection of superior lines for agro-morphological characters in 104 germplasm accessions of rapeseed and mustard

\begin{tabular}{|c|c|}
\hline Characters & Accessions \\
\hline Day to 50 percent flowering & $1389,928,1319,1450,1472$ \\
\hline Day to 100 percent flowering & $1389,928,1319,1450,1472$ \\
\hline Days to maturity & |480, |48I, | 482, |489, I497 \\
\hline Plant Height & 2493I, I493, 2492I, 24928, 24924 \\
\hline Number of branches per plant & |32|, 24943, I387 \\
\hline Number of silique per raceme & $24724,24720,24725,247|2,247| 3$ \\
\hline Raceme length & $26827,24944, \mid 1494,1495$ \\
\hline Stem diameter & $1648,26827,24943$ \\
\hline Number of leaves per plant & |387, 24708, 247|9 \\
\hline Pedicel Length & $1495,1493,1472$ \\
\hline Leaf length & 24705, 24706, 247II, 2492।, 24707 \\
\hline Leaf width & |474, 2492।, I477, 24956, 247|8 \\
\hline Silique width & |480 I478 I459 I 464 I489 I473 I468 \\
\hline Seeds per silique & I449, 93।, I496, I454, I 455 \\
\hline I00 Grain weight & $2492 I,|498,247| 2,24726$ \\
\hline
\end{tabular}

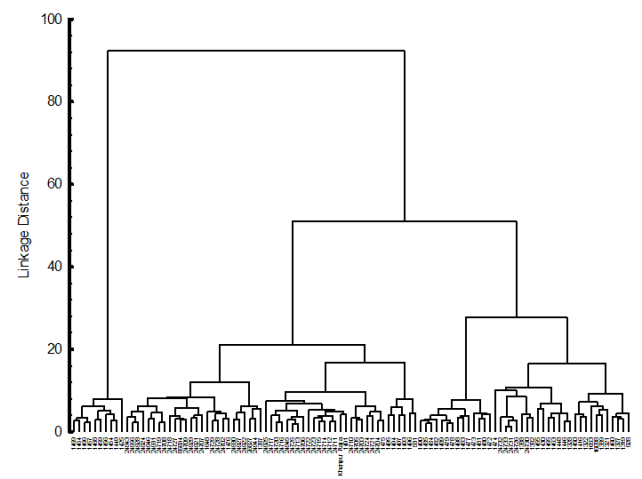

Figure 2 Cluster analysis using wards method in 104 germplasm accessions and check variety of rapeseed and mustard.

\section{Acknowledgments}

None.

\section{Conflicts of interest}

The author declares there are no conflicts of interest.

\section{Funding details}

None.

\section{References}

1. Farooq O. Agriculture. In: Wasti SE, editor. Pakistan Economic Survey, 2012-2013. Ministry of Finance, Government of Pakistan, Islamabad. 2013.

2. Khan SB, A Khattak, Hafeezullah A Rehman. Agricultural Statistics of Pakistan. Pakistan Bureau of Statistics, Statistics Division, Government of Pakistan. 2013.

3. Ana MJ, KS Ankica, SP Dejana, et al. Phenotypic and molecular evaluation of genetic diversity of rapeseed (Brassica napus L.) genotypes. African Journal of Biotechnology. 2009;8(19):4835-4844.

4. Cowling WA. Genetic diversity in Australian canola and implications for crop breeding for changing future environments. Field Crops Research. 2007; 104:103-111.

5. Nasim A, Farhatullah S Iqbal, S Shah, et al. Genetic variability and correlation studies for morphological characters in Brassica napus L. Pak J Bot. 2013;45(4):1229-1234.

6. Khan FU, R Uddin, IA Khalil. Correlations and Factor Wise Contributions of Various Traits Related to Yield in Rapeseed (Brassica napus L.). American-Eurasian J Agric \& Environ Sci. 2013;13(1):101-104.

7. Geraci A, Divaret I, Raimondo FM, et al. Genetic relationships between Sicilian wild populations of Brassica analysed with RAPD markers. Plant Breed. 2001;120:193-196.

8. Xu DH, Gai JY. Genetic diversity of wild and cultivated soybeans growing in China revealed by RAPD analysis. Plant Breed. 2003;122:503-506.

9. Pankovic D, Sakac Z, Jocic S, et al. Molecular markers in sunflower breeding. A periodical of Scientific Research on Field and Vegetable Crops. 2004;40:301-311.

10. Prasad B, Babar MA, Xu XY, et al. Genetic diversity in the U.S. hard red winter wheat cultivars as reveled by microsatellite markers. Crop Pasture Sci. 2009;60:16-24. 